\title{
Personal Hygine dan infeksi cacing Enterobius vermicularis Pada Anak Usia Pra Sekolah
}

\section{Personal Hygine and Enterobius vermicularis worm infections in pre-school children}

Indra Elisabet Lalangpulinga, Pricilya Omega Manengalb, Ketrina Konoralmac

Jurusan Teknologi Laboratorium Medis, Politeknik Kesehatan Kemenkes Manado, Indonesia

\section{A B S T R A C T / A B S T R A K}

\begin{abstract}
Enterobiasis is a disease caused by worm infection Enterobius vermicularis that is commonly suffered by children. Transmission of Enterobius vermicularis is partly due to a lack of attention to personal hygiene. This research is descriptive in order to find out personal hygine and Enterobius vermicularis worm egg infection in pre-school children aged 3-6 years in the village Betelen 1, Southeast Minahasa Regency. The samples examined were 31 samples consisting of 3 years old children as much as 37\%, 4 years as much as 29\%, 5 years as much as 23\% and 6 years as much as 10\%. This research was conducted by taking primary data from observations and examinations using the method periplaswab. The results showed as many as 8 children $(25.81 \%)$ positive found the worm eggs Enterobius vermicularis with behavior poor hygiene, as many as $48 \%$ had the habit of not washing their hands before eating and $32 \%$ had the habit of sucking their fingers.
\end{abstract}

Keywords: Enterobius vermicularis; children 3-6 years old

\begin{abstract}
Enterobiasis adalah penyakit yang disebabkan oleh infeksi cacing Enterobius vermicularis yang banyak dialami oleh anak-anak. Penularan "Enterobius vermicularis" antara lain disebabkan karena kurangnya memperhatikan kebersihan dari perseorangan (Personal hygiene). Penelitian ini bersifat deskriptif untuk mengetahui personal hygine dan infeksi telur cacing Enterobius vermicularis pada anak usia pra sekolah. Sampel yang diperiksa sebanyak 31 sampel yang terdiri dari anak berusia 3 tahun sebanyak 37\%, 4 tahun sebanyak 29\%, 5 tahun sebanyak 23\% dan 6 tahun sebanyak 10\% .Penelitian ini dilakukan dengan pengambilan data primer dari hasil observasi dan pemeriksaan dengan menggunakan metode periplaswab. Hasil penelitian menunjukkan sebanyak 8 anak $(25,81 \%)$ positif ditemukan adanya telur cacing Enterobius vermicularis dengan perilaku kebersihan yang masih belum baik yaitu sebanyak $48 \%$ memiliki kebiasaan tidak mencuci tangan sebelum makan dan 32\% memiliki kebiasaan menghisap jari.
\end{abstract}

Kata Kunci : Enterobius vermicularis; anak 3-6 tahun

Copyright $\odot 2020$ Jurnal Kesehatan Lingkungan

All right reserved

*Alamat korespondensi : email : indra_elisabet@yahoo.com

\section{PENDAHULUAN}

Infeksi cacing merupakan salah satu penyakit yang tersebar dan menginfeksi banyak manusia di seluruh dunia. Sampai saat ini penyakit cacing masih tetap merupakan suatu masalah karena kondisi sosial dan ekonomi di beberapa bagian dunia. Pada umumnya infeksi cacing, jarang menimbulkan penyakit serius tetapi dapat menyebabkan gangguan kesehatan kronis yang berhubungan dengan faktor higienitas dan ekonomi. Cacingan merupakan penyakit endemik dan kronik dengan prevalensi tinggi yang tidak mematikan, tetapi menggerogoti kesehatan tubuh manusia sehingga berakibat menurunnya kondisi gizi dan 

secara simultan oleh beberapa jenis cacing sekaligus, yang populer sebagai parasit saat ini adalah cacing gelang (Ascaris lumbricoides), cacing kremi (Enterobius vermicularis), cacing pita (Taenia solium) dan cacing tambang (Ancylostoma duodenale). Diperkirakan lebih dari 60\% anak-anak di Indonesia menderita suatu infeksi cacing, penyebabnya adalah rendahnya mutu sanitasi. Pada anak-anak, cacingan akan berdampak pada gangguan kemampuan untuk belajar, menurunkan berat badan, mempengaruhi kecerdasan, dan pada orang dewasa menurunkan kualitas sumber daya manusia1.

Salah satu faktor yang menyebabkan terjadinya penularan Enterobius vermicularis antara lain adalah suhu udara, dimana infeksi di daerah dingin lebih tinggi daripada di daerah panas. Hal ini mungkin disebabkan pada umumnya orang di daerah dingin jarang mandi dan mengganti pakaian dalam. Debu yang menempel dipakaian setelah beraktifitas dan tidak diganti merupakan salah satu faktor terjadinya penularan penyakit kecacingan Enterobius vermicularis. Penyebaran cacing ini juga ditunjang oleh eratnya hubungan manusia antar manusia satu dengan yang lain serta lingkungan yang sesuai2.

Berdasarkan hasil penelitian yang telah dilakukan oleh Budi Hairani dan Annida di Kabupaten Tanah Bumbu Kalimantan Selatan didapatkan hasil yang menyatakan bahwa 2,7\% anak di pedesaan terinfeksi Enterobius vermicularis. Adapun penelitian yang dilakukan oleh Erlieza Rosdania di SD Bendosari Sukoharjo, dari 45 anak didapatkan 8 anak terinfeksi enterobiasis yaitu 5 anak $(62,5 \%)$ dengan personal hygiene buruk terkena enterobiasis dan 3 anak $(8,1 \%)$ dengan personal hygiene baik terkena enterobiasis 3,4 .

Di Puskesmas Tombatu tidak menunjukkan informasi mengenai kasus kacacingan karena di Puskesmas Tombatu tidak dilakukan pemeriksaan mengenai kecacingan, meskipun anak-anak yang ada di desa Betelen 1 menderita penyakit kecacingan berdasarkan beberapa warga penduduk bahwa pada malam hari anak-anak mengalami rasa gatal dan menggaruk kulit disekitar rektal. Berdasarkan observasi awal yang dilakukan, masyarakat yang ada di desa setempat menganggap bahwa kecacingan bukanlah suatu penyakit yang berbahaya bagi kesehatan dan sudah sangat lazim terjadi pada anak-anak. Masyarakat di Desa Betelen 1 pada umumnya mengesampingkan penyakit cacingan sehingga masyarakat tidak melaporkan maupun membawa anak-anak mereka ke pusat kesehatan masyarakat untuk mendapatkan penanganan dari petugas kesehatan dikarenakan

kurangnya pengetahuan masyarakat tentang resiko kecacingan. Pemberian obat secara tradisional yang dilakukan oleh masyarakat setempat dengan menggosokkan bawang putih (Allium sativum) disekitar rektal dan makan sayur leilem (Cleodendrum minahassae) diyakini sangat berkhasiat dan berhasil dalam pemberantasan telur cacing pada anak-anak yang menderita cacingan. Penggunaan obat tradisional yang dilakukan oleh masyarakat setempat masih banyak dijumpai karena mudah didapatkan dan lebih murah jika dilihat dari segi ekonomis. Tujuan penelitian ini adalah untuk mengetahui personal hygine dan keberadaan telur cacing nematoda usus Enterobius vermicularis pada anak- anak usia 3-6 tahun di Desa Betelen 1, Kecamatan Tombatu, Kabupaten Minahasa Tenggara.

\section{METODE}

Jenis penelitian ini bersifat deskriptif. Waktu penelitian berlangsung bulan November 2018 - Juni 2019. Sampel pada penelitian ini sebanyak 31 orang dengan menggunakan teknik Purposive sampling dengan kriteria responden memiliki salah satu dari gejala klinis terinfeksi Enterobius vermicularis yaitu rasa gatal hebat di sekitar anus, menjadi rewel, kurang tidur, nafsu makan berkurang, berat badan menurun, kulit di sekitar anus menjadi lecet atau infeksi. Pengambilan sampel dengan metode periplaswab yaitu pengambilan sampel dengan cara menempelkan selotip pada bagian anus dan selanjutnya diperiksa dibawah mikroskiop pada pembesaran 10x dan 40 x. Penelitian ini dilaksanakan berdasarkan rekomendasi etik penelitian yang dikeluarkan oleh Komisi Etik Penelitian Kesehatan Poltekkes Kemenkes Manado No. 211/KEPK/VII/2019.

\section{HASIL}

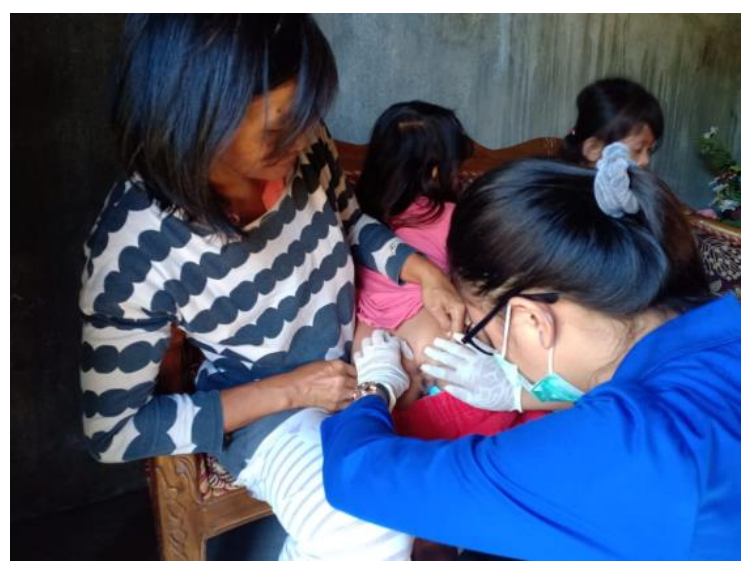

Gambar 1. Pengambilan sampel dengan metode periplaswab 
Tabel 1. Distribusi Responden Menurut Umur di Desa Betelen 1, Kecamatan Tombatu, Kabupaten Minahasa Tenggara Tahun 2019

\begin{tabular}{lll}
\hline Umur Responden & F (jumlah) & $(\%)$ \\
\hline 3 Tahun & 12 & 38.71 \\
4 Tahun & 9 & 29,03 \\
5 Tahun & 7 & 22,58 \\
6 Tahun & 3 & 9,68 \\
\hline Total & 31 & 100 \\
\hline
\end{tabular}

Tabel 1 menunjukkan jumlah responden terbanyak berusia 3 tahun yaitu sebanyak $38,71 \%$

Tabel 2. Hasil Pemeriksaan telur cacing Enterobius vermicularis

\begin{tabular}{lll}
\hline Hasil Pemeriksaan & F & $(\%)$ \\
\hline Positif & 8 & 25,81 \\
Negatif & 23 & 74,19 \\
\hline Total & 31 & 100 \\
\hline
\end{tabular}

Hasil pemeriksaan mikroskopis ditunjukkan pada tabel 2 yaitu sebanyak $25,81 \%$ menderita enterobiasis

Tabel 3. Distribusi Responden Berdasarkan Perilaku Mencuci Tangan

\begin{tabular}{lll}
\hline Perilaku & $\mathrm{F}$ & $(\%)$ \\
\hline $\begin{array}{l}\text { Mencuci tangan dengan sabun } \\
\text { sebelum makan }\end{array}$ & 16 & 51,61 \\
$\begin{array}{l}\text { Tidak Mencuci tangan dengan } \\
\text { sabun sebelum makan }\end{array}$ & 15 & 48,39 \\
\hline Total & 31 & 100 \\
\hline
\end{tabular}

Perilaku kebersihan balita yaitu mencuci tangan dengan sabun sabun ditunjukkan pada Tabel 3 yaitu sebanyak $48,39 \%$ masih berprilaku tidak mencuci tangan dengan sabun sebelum makan.

Tabel 4. Distribusi Responden Berdasarkan Perilaku Menghisap Jari

\begin{tabular}{lll}
\hline Perilaku & $\mathrm{f}$ & $(\%)$ \\
\hline Menghisap jari & 10 & 32,26 \\
Tidak menghisap jari & 21 & 67.74 \\
\hline Total & 31 & 100 \\
\hline
\end{tabular}

Tabel 4 menunjukkan sebanyak 32,26\% responden memiliki kebiasaan menghisap jari.

\section{PEMBAHASAN}

Enterobius vermicularis biasa disebut dengan cacing kremi atau penyebab terjadinya Enterobiasis yang pada umumnya menyerang anak-anak, hal ini disebabkan karena anak-anak biasanya belum bisa menjaga pola hidup bersih dan sehat kemudian tubuhnya juga masih rentan terhadap penyakit. Penelitian yang telah dilakukan sebelumnya oleh Erlieza Rosdania, di SD Bendosari Sukoharjo didapatkan hasil yang menyatakan bahwa terdapat hubungan yang signifkan antara personal hygiene dan kejadian infeksi enterobiasis4.

Enterobius vermicularis merupakan nematoda usus yang habitatnya berada di usus besar rectum yang menular dari tangan ke mulut setelah menggaruk perianal (Autoinfeksi), atau tangan yang telah tersentuh perianal menyebarkan ke orang lain setelah memegang benda-benda dan pakaian; debu juga merupakan sumber infeksi.

Hasil pemeriksaan telur cacing Enterobius vermicularis dari 31 sampel yang diperiksa 8 diantaranya positif terinfeksi Enterobius vermicularis sedangkan 23 lainnya negatif atau tidak terinfeksi Enterobius vermicularis. Berdasarkan hasil pengamatan langsung yang telah dilakukan pada 8 anak yang positif terinfeksi Enterobius vermicularis pada umumnya belum melakukan personal hygiene dengan baik. Kondisi rumah responden masih berlantaikan tanah. Penggunaan sprei yang sudah kotor dan tidak diganti serta jamban yang digunakan tidak memiliki septic tank yang memenuhi standard kesehatan juga merupakan faktor pendukung terjadinya kejadian kecacingan.

Berdasarkan perilaku mencuci tangan didapatkan hasil bahwa responden yang memiliki kebiasaan mencuci tangan dengan sabun sebelum makan yaitu $51.61 \%$ sedangakan responden yang tidak memiliki kebiasaan mencuci tangan dengan sabun yaitu $48,39 \%$. Enterobiasis dapat ditularkan melalui penularan secara langsung, dimana anakanak menggaruk bagian anus yang terinfeksi sehingga telur cacing tertinggal di kuku atau jari. Ketika anak memiliki kebiasaan menghisap jari maka proses auto infeksi dapat terjadi dan pengobatan menjadi tidak efektif. Hasil ini sejalan dengan penelitian yang dilakukan bahwa ada hubungan bermakna antara kejadian kecacingan dengan perilaku mencuci tangans. 
Hasil penelitian menunjukkan sebanyak 8 anak $(25,81 \%)$ positif ditemukan adanya telur cacing Enterobius vermicularis dengan perilaku kebersihan (personal hygine) yang masih belum baik yaitu sebanyak $48 \%$ memiliki kebiasaan tidak mencuci tangan sebelum makan dan $32 \%$ memiliki kebiasaan menghisap jari.

\section{SARAN}

Dari hasil penelitian yang diperoleh, disarankan untuk memberikan edukasi kepada orang tua yang mengasuh anak tersebut sehingga dapat terjadi perubahan perilaku dan memperbaiki sanitasi lingkungan yang ada sehingga dapat memutuskan mata rantai penularan penyakit kecacingan khususnya Enterobius vermicularis.

\section{UCAPAN TERIMA KASIH}

Diucapkan terimakasih kepada semua pihak yang telah membantu dalam pelaksanaan penelitian ini khususnya bagi petugas kesehatan dari Puskesmas Tombatu 1, Kecamatan Tombatu, Kabupaten Minahasa Tenggara.

\section{DAFTAR PUSTAKA}

1. Zulkoni, H. A. Parasitologi. Yogyakarta: Nuha Medika. 2011.

2. Sutanto, I. I. Parasitologi Kedokteran. Jakarta: Balai Penerbit FKUI. 2008.

3. Hairani,B.,Annida. Insidensi parasit pencernaan pada anak sekolah dasar di perkotaan dan pedesaan di Kabupaten Tanah Bumbu Kalimantan Selatan. Jurnal 